\title{
EVALUATION OF PATIENT SATISFACTION TOWARDS PHARMACY SERVICES AT HOSPITAL OUTPATIENT PHARMACIES IN PADANG
}

\author{
Sara Surya* \\ Sefrianita Kamal \\ Lusia Eka Putri \\ Keywords: \\ Satisfaction \\ Patients \\ Pharmacy Services \\ Outpatient Services \\ Hospitals in Padang
}

Universitas Dharma Andalas,

Padang, West Sumatra, Indonesia

*email: sar4surya@gmail.com
(C) 2019 The Authors. Published by Institute for Research and Community Services Universitas Muhammadiyah Palangkaraya. This is Open Access article under the CC-BY-SA License (http://creativecommons.org/licenses/by-sa/4.0/). DOI: https://doi.org/l0.33084/bjop.v2il.57I.

\section{INTRODUCTION}

Hospital is a health service institution that organizes individual health services comprehensively that provides inpatient, outpatient, and emergency services (Government of the Republic of Indonesia, 2009). The pharmaceutical service is a direct and responsible service to patients related to pharmaceutical preparations with the aim of achieving definite results to improve the quality of patients' life (Al-Quteimat \& Amer, 2016). Patient satisfaction with the quality of pharmaceutical services is an important indicator in the quality of health services in hospitals (Insani et al., 2017).

Service quality is said to be good and satisfying if the services received are in accordance with or exceeding expectations, otherwise service quality is said to be poor or unsatisfactory if the service received is lower than expected (Supranto, 200I). The level of patient satisfaction can be measured using an instrument in the form of a questionnaire (Al-Abri \& Al-Balushi, 20I4). Satisfaction affects patients to return to the hospital and redeem drugs at the same pharmacy when needed. If patients are satisfied, not only patients will benefit, but also hospitals, especially pharmaceutical installations, will be promoted (Yang et al., 2016).

Pharmaceutical Service Standards are benchmarks that are used as guidelines for pharmacy personnel in organizing pharmaceutical services (Dargahi \& Khosravi, 2010). Meanwhile, Pharmaceutical Services is a direct and responsible service to patients related to pharmaceutical preparations with the aim of achieving definite results to improve the quality of patients life (Government of the Republic of Indonesia, 2009). Customer satisfaction analysis is based on five dimensions of service quality, namely responsiveness, reliability, assurance, empathy, and tangible (Mulia, 2017).

I. Reliability is hospitals ability to provide services in accordance with the promised accurately and reliably.

2. Responsiveness is a policy to help and provide services quickly and precisely to patients with clear information. 
3. Assurance is knowledge, politeness and the ability of hospital staff to foster trust in patients. This includes several components including communication, credibility, security, competence, and courtesy.

4. Direct evidence (tangibles) is the ability of the hospital to show its existence to external parties. The appearance and ability of the facilities and physical infrastructure of a hospital that can be relied upon by the condition of the surrounding environment are clear evidence of the services provided by the service provider.

5. Empathy is to give genuine and individual or personal attention given to customers by trying to understand the wishes of patients.

Outpatient pharmacies are an important part of the hospital complex system which has a direct effect on patient satisfaction and the reputation of the hospital. The patient is easily tired and impatient when waiting in line too long to get medicine before leaving the hospital (Surur et al., 2015). Meanwhile, with increasing awareness of consumer rights protection and increasingly intense competition between hospitals, patient-oriented ideas have become the focus of every hospital. Thus, knowledge of pharmacy services at the Pharmacy Outpatient services is important in many aspects, and this is one of the goals of modern scientific management research (Dan et al., 2016).

\section{MATERIAL AND METHODS}

The design of this study was a cross-sectional study. Research subjects were patients from hospital outpatient pharmacies in Padang City. The instruments used in this study were recording devices, questionnaires, research permits each hospital outpatient pharmacies located in the Padang City.

\section{Data Analysis}

Satisfaction was assessed by giving questionnaires to respondents then questionnaires were analyzed descriptively. Assessment of patient satisfaction was done by taking data through a questionnaire of 100 respondents. Satisfaction analysis was carried out using a Likert scale, then data was displayed in a cartesian form.

\section{RESULTS AND DISCUSSION}

The population was all patients/families of hospital outpatient in Padang and the sample was 100 respondents. This is in accordance with the sampling exclusion criteria. 100 respondents who were sampled had redeemed medicines at the hospital outpatient pharmacies in Padang and directly felt the use of pharmaceutical services at the hospital. The respondents of the study were 100 persons which were nominated by 56 women 44 men. The highest age of respondents was between $26-25$ as many as 28 persons and the lowest age was between 75-85 namely I person. The education level of the correspondent consists of 49 persons high school graduates, while the highest graduates are Master with 5 persons. The respondent characteristics is shown in Table I.

Table I. Respondent Characteristics

\begin{tabular}{lc}
\hline Gender & Number of persons \\
\hline Men & 44 \\
Women & 56 \\
\hline Old (Years) & \\
\hline I5-25 & 23 \\
$26-35$ & 28 \\
$36-45$ & 14 \\
$56-55$ & 15 \\
$56-65$ & 9 \\
$66-75$ & 1 \\
$75-85$ & 1 \\
\hline Level of Education & \\
\hline Elementary & 11 \\
Junior High School & 10 \\
Senior High School & 49 \\
Diploma & 8 \\
Bachelor & 17 \\
Master & 5 \\
\hline
\end{tabular}

Research instrument testing was conducted to determine the validity and reliability of research instruments before being used for actual data screening. The instruments used in the research are those that have to fulfill valid and reliable criteria, based on the results of the validity and reliability tests that have been carried out. The indicator in this study was an 
independent variable consisting of reliability, responsiveness, empathy, assurance, and physical evidence.

From the results of data processing using the SPSS 22 program. The frequency value of reliability category in the first question were obtained that $2 \%$ of respondents were not satisfied, $1 \%$ of respondents was less satisfied, $21 \%$ of respondents were satisfied, $37 \%$ of respondents were satisfied enough, and $39 \%$ of respondents were very satisfied.

The frequency value of reliability category in the second question were obtained that $1 \%$ of respondents was not satisfied, $7 \%$ of respondents were less satisfied, $29 \%$ of respondents were satisfied, $38 \%$ of respondents were satisfied enough, and $39 \%$ of respondents were very satisfied.

The frequency value of reliability category in the third question were obtained that $2 \%$ of respondents were not satisfied, $5 \%$ of respondents were less satisfied, $24 \%$ of respondents were satisfied, $45 \%$ of respondents were satisfied enough, and $24 \%$ of respondents were very satisfied.

The frequency value of reliability category in the fourth question were obtained that $14 \%$ respondents were less satisfied, $22 \%$ of respondents were satisfied, $48 \%$ of respondents were satisfied enough, and $8 \%$ of respondents were very satisfied.

The frequency value of reliability category in the fifth question were obtained that $1 \%$ of respondents was not satisfied, $17 \%$ of respondents were less satisfied, $22 \%$ of respondents were satisfied, $39 \%$ of respondents were satisfied enough, and $21 \%$ of respondents were very satisfied.

The frequency value of reliability category in the sixth question were obtained that $2 \%$ of respondents were not satisfied, $9 \%$ of respondents were less satisfied, $30 \%$ of respondents were satisfied, $39 \%$ of respondents were satisfied enough, and $20 \%$ of respondents were very satisfied.

The frequency value of reliability category in the seventh question were obtained that $3 \%$ of respondents were less satisfied, $39 \%$ of respondents were satisfied, $33 \%$ of respondents were satisfied enough, and $25 \%$ of respondents were very satisfied.

Lastly, the frequency value of reliability category in the eight-question were obtained that $1 \%$ of respondents was not satisfied, $8 \%$ of respondents were less satisfied, $27 \%$ of respondents were satisfied, $43 \%$ of respondents were satisfied enough, and $21 \%$ of respondents were very satisfied.

To improve patient satisfaction in hospital located in Padang, the authorities need to make improvements in several aspects. The results of interviews with respondents indicated several things that could be done, including:

I. Maintain the cleanliness of the building; complete the medicine according to the patients' demand, as well as a comfortable and spacious waiting room.

2. Speed up drug delivery services because many respondents complained about the length of service.

3. Sympathetic attitude of the officers so that patients are happier in utilizing hospital pharmacy facilities in Padang

4. Clear information is given to the patient/family of the patient about all drugs that are given such as how to use, side effects, and how to store them.

5. Increase the number of employees, because the number of people queuing in one day is quite a lot.

\section{CONCLUSION}

From the distribution of questionnaires to 100 respondents, it was found that they were satisfied with the pharmacy services at the hospital pharmacies in Padang. The service system provided by pharmacists 
and pharmacist assistants is good, except that drug information and counseling need to be improved.

\section{REFERENCES}

Al-Abri, R., Al-Balushi, A. 20I4. Patient Satisfaction Survey as a Tool Towards Quality Improvement. Oman Medical Journal. 29(I):37.

Al-Quteimat, O.M., Amer, A.M. 2016. Evidence-based pharmaceutical care: The next chapter in pharmacy practice. Saudi Pharmaceutical Journal. 24(4):447-45I.

Dan, Z., Xiaoli, H., Weiru, D., Li, W., Yue, H. 2016. Outpatient pharmacy optimization using system simulation. Procedia Computer Science. 9| (2016):27-36.

Dargahi, H., Khosravi, S.H. 2010. Hospitals Pharmacy Quality Assurance System Assessment in Tehran University of Medical Sciences, Iran. Iranian Journal of Public Health. 39(4): I02-I I 3.

Government of the Republic of Indonesia. 2009. Law No. 44 about Hospitals.

Insani, S.D., Hakim, L., Widyaningrum, K. 2017. The Effect of Outpatient Pharmaceutical Service Quality on Patient Loyalty Through Patient Satisfaction of Karsa Husada General Hospital Batu. Jurnal Aplikasi Manajemen. I5(4):616-623.

Mulia, D.S. 2017. Tingkat Kepuasan Pasien Umum Rawat Jalan terhadap Kualitas Pelayanan Instalasi Farmasi RSUD Dr. Doris Sylvanus Palangka Raya. Jurnal Surya Medika. 2(2):4048.

Supranto, J. 200I. Pengukuran Tingkat Kepuasan Pelanggan. Jakarta: Rineka Cipta.

Surur, A.S., Teni, F.S., Girmay, G., Moges, E., Tesfa, M., Abraha, M. 20I5. Satisfaction of clients with the services of an outpatient pharmacy at a university hospital in northwestern Ethiopia: a cross-sectional study. BMC Health Services Research. 15:229.

Yang, S., Kim, D., Choi, H.J., Chang, M.J. 2016. A comparison of patients' and pharmacists' satisfaction with medication counseling provided by community pharmacies: a crosssectional survey. BMC Health Services Research. 16:131. 